\title{
Getting relief to marginalised minorities: the response to cyclone Komen in 2015 in Myanmar
}

\author{
Isabelle Desportes (1D
}

\begin{abstract}
Little academic research has examined the challenges humanitarian actors face or the strategies they develop in the increasingly numerous authoritarian and low-intensity conflict settings. Based on 4 months of qualitative fieldwork in Myanmar in 2017-2018, this article explores how civil society organisations, international nongovernmental organisations, international organisations, and donor agencies tried to provide relief to marginalised minorities in the ethnic States of Chin and Rakhine following Cyclone Komen in 2015. The study findings detail how civil society actors mobilised parallel minority and Christian networks and lobbied international actors to support disaster victims of Chin ethnicity. In Rakhine State, it was overwhelmingly international humanitarians who were able and willing to support Muslims, including the Rohingya. This increased tensions among community groups and between Myanmar and the international community. Particularly in the context of rising identity politics, humanitarian governance encompasses the governance of perceptions. Trade-offs between long-term acceptance and following humanitarian principles in aid allocation are largely unavoidable and must be carefully considered.
\end{abstract}

Keywords: Humanitarian aid, Disaster response, Flood, Conflict, Identity politics, Minority groups, Civil society, Myanmar, Case study

\section{Introduction}

When massive floods hit Myanmar's ${ }^{1}$ Rakhine State in summer 2015, members of the Muslim Rohingya minority fled their homes to seek refuge in government shelters. However, unlike their Buddhist neighbours, the Rohingya were turned away. They could have stayed at the shelters if they had signed documents identifying themselves as Bengalis, but they were very unlikely to do this. For decades, the Rohingya have battled to gain the official recognition as an ethnic group necessary to obtain Myanmar citizenship, which the Myanmar constitution ties to belonging to a recognised 'national race' (Cheesman 2017; Parnini 2013).

The above events were reported by The Burma Times (2015), an exile diaspora newspaper. They may have actually occurred, but the story may also simply be one bullet in the discursive battle surrounding the treatment

Correspondence: desportes@iss.nl

International Institute of Social Studies, Erasmus University Rotterdam, P.O. Box 29776, 20502 LT The Hague, The Netherlands of Myanmar's multiple ethnic and religious minorities. ${ }^{2}$ In Myanmar, nationalist discourses 'othering' those who are not Buddhist or ethnically Bamar have permeated the societal, political and law-making spheres (Farzana 2015, pp. 297-298; Lee 2016; Renshaw 2013; Wade 2017). Regardless of its veracity, the story calls for a closer look at the marginalisation minority groups faced in the 2015 disaster response after flooding and landslides were triggered by a heavy monsoon season and compounded by the cyclone Komen throughout Myanmar. Most importantly, the story raises questions regarding how members of Myanmar's vibrant civil society and international humanitarians navigated a context where conflict and identity politics played out during the response. Although challenges confronting civil society and humanitarian actors in authoritarian and conflict-affected contexts have been explored (e.g., Harvey 2013; Kahn and Cunningham 2013; del Valle and Healy 2013; Desportes et al. 2019), very little academic research has investigated the practices developed to overcome them. 
Based on 4 months of qualitative fieldwork, this article aims to describe the challenges and navigation strategies associated with supporting minority groups, as perceived and recounted by representatives of civil society organisations (CSOs), international non-governmental organisations (INGOs) and international organisations (IOs) that were part of the 2015 disaster response in Chin and Rakhine States. These states were chosen as the two ethnic regional states most impacted by the disasters, presenting different minority tension dynamics, and fieldwork possibilities.

The case studies on minority support following the 2015 disasters inform two broader debates. The first concerns the understudied disaster-conflict nexus (King and Mutter 2014). How conflict and disaster dynamics interact is particularly poorly understood in settings of low-intensity conflict (LIC), which are predominantly caused by intra-state political and social tensions (Heidelberg Institute for International Conflict Research [HIIK] 2016). Worldwide, most current conflicts are LICs (HIIK 2016; Human Security Report Project 2013). Focusing on how disaster response is shaped towards minoritiesgroups collectively identifying around characteristics such as ethnic origin, religion, culture, or language (Azar 1990) - places a magnifying glass on core LIC-disaster dynamics. This is especially true in a context of rising identity politics, where certain groups are marginalised in the politicised response, creating difficulties for humanitarian actors who remain political players despite their actions being driven by moral rather than political norms (Kahn and Cunningham 2013; del Valle and Healy 2013).

The second debate involves minorities as a core friction point in discussions on humanitarians' interference in national state affairs (humanitarianism-sovereignty tensions). Kahn and Cunningham (2013, p. 39) note that, in recent decades, a 'fundamental gap has developed between states and international humanitarian actors in terms of describing what sovereignty entails and how it is expressed' and that how these tensions can be managed, especially by humanitarian actors, needs to be better understood. The well-being of people caught up in crises constitutes the contested ground on which states and humanitarian actors clash' (Kahn and Cunningham 2013, p. 139). Often, especially in authoritarian states, and certainly in Myanmar (Décobert 2016; Matelski 2016b; Smith 2010), contestation over minorities' welfare and rights is particularly intense.

\section{Challenges and social navigation practices to support minorities in authoritarian low-intensity conflict settings}

As politically and socially shaped events, disaster response processes reveal the dynamics criss-crossing society, state and aid relations (Pelling and Dill 2010;
Hutchison 2014). This is particularly true in countries fraught by conflict, although it is important to differentiate among conflict types (van Voorst and Hilhorst 2017). LICs are marked by fewer violent events and deaths compared with high-intensity conflicts (HIIK 2016), but LICs show high levels of volatility and structural violence, such as the marginalisation of minority groups by the state (Azar 1990). Disaster response can then be the very conduit through which the LIC is played out, further side-lining minorities, harming political opponents or increasing political support (cf. Jacoby and Özerdem 2008 [Turkey]; Flanigan 2008 [Lebanon and Sri Lanka]; Desportes et al. 2019 [Ethiopia]). When a disaster strikes a LIC setting, state and societal actors are likely to contest each other's legitimacy, capacity and will to protect disaster victims-for instance, by accusing government authorities of not letting members of ethnic or religious minorities into flood shelters.

Authoritarian LIC settings present specific challenges for civil society and international disaster responders. Authoritarian practices, defined as 'patterns of action that sabotage accountability to people over whom a political actor exerts control, or their representatives, by means of secrecy, disinformation and disabling voice' (Glasius 2018, p. 517), translate into restrictions on information, right to expression and to assembly. Médecins Sans Frontières (MSF), an INGO, have reported state restrictions on 'geographic access, programmatic options, and modalities of work' in the authoritarian contexts of Sri Lanka, Uzbekistan, Turkmenistan and Myanmar (del Valle and Healy 2013, p. 198). In Ethiopia, civil society and international actors have described their inability to freely shape aid provision because of the governmental 'iron cage of bureaucracy' and restricted civil society space (Desportes et al. 2019, p. 19). Humanitarian independence is put to the test when LIC dynamics enter into the disaster response process and question the impartiality of aid delivery, but this cannot be openly discussed under strict state control (Desportes et al. 2019). For instance in Myanmar, for decades following the 1960s, and also more recently during the Rohingya crisis, organisations, journalists, researchers and activists who wrote critically about the regime were blacklisted, banned or denied entry to the country (Selth 2018, p. 6).

Glasius et al. (2018) highlight the sense of uncertainty prevalent under authoritarian regimes, stressing the arbitrariness of state decisions and the context-specific 'fluid lines' that make what is permissible ambiguous. In addition to the 'big politics' that may clearly restrict access or operations, seemingly softer 'everyday politics' unfold (Hilhorst 2013, p. 232), and the quiet, mundane practices of state bureaucracy can restrict aid permissions in more duplicitous ways. A travel authorisation being held up by 'bureaucratic delays' would be more 
difficult to contest on humanitarian grounds than would a clear refusal to grant access to an area. The functioning of mostly opaque state institutions (Kahn and Cunningham 2013) adds uncertainty, as do LIC dynamics. High tensions between ethnic, religious and/or societal groups and the state increase the risk of arbitrary 'snap decisions' and unpredictable eruptions of violence (Azar 1990; Galtung 1996; Kalyvas 2003). This results not only in state-imposed limitations on non-governmental actors; the same actors also internalise self-censorship practices because of fear of over-stepping the fluid lines or escalating tensions (Desportes et al. 2019).

Whether actors choose to self-censor or to act and speak out depends partially on their 'actor pedigree' (Douma and Hilhorst 2006; Schennink et al. 2006). For example, denouncing a breach of humanitarian principles better fits the institutional model, mandate and habitus of the privately funded and testimony-oriented INGO MSF ${ }^{3}$ than that of the domestic National Red Cross Red Crescent Society, which is legally auxiliary to the state. Which risks can be taken also depends on actors' capacity to 'disentangle themselves from confining structures, plot their escape and move towards better positions' (Vigh 2009, p. 419). Detailing what he refers to as social navigation processes, Vigh (2009) draws a parallel with Jackson's (1998) concept of 'manoeuvring', the striving for balance and control. Social navigation directs the analytical gaze not towards structures and boundaries actors face or how they act in their social environment, but rather towards how actors 'interact with their social environment and adjust their lives to the constant influence [...] of social forces and change' (Vigh 2009, p. 433). As such, social navigation is a good fit for understanding the daily practices of actors seeking to reach a specific goal (here, minority support), in a context of restrictive and uncertain space to manoeuvre.

\section{Civil society actors}

Previous research shows civil society actors to be particularly skilled social navigators. In Myanmar, the phrase 'civil society' is generally used to denote 'any group or initiative that is not directly piloted by the government' aiming to advance common interests (Desaine 2011, pp. 12-13; Centre for Peace and Conflict Studies 2009 , p. 6). CSOs can be divided into community-based organisations (CBOs), primarily linked to a specific ethnic or religious group, and the more Western-oriented, officially registered local non-governmental organisations (LNGOs). Civil society actors are deeply embedded in and knowledgeable about the dynamics of the area where they operate. CSOs in Myanmar have accumulated decades of experience responding to 'conflict, oppressive structures, and natural disaster through self-organisation, self-protection, and covert resistance' (Matelski 2016b, p. 24).

In Myanmar, 'ethnic identity [...] is complex, politically charged and highly determinant of people's personal and political identities and associations/affiliations' (Drew 2016, p. 8), and ethnicity and religion constitute prime fault lines of civil society (Matelski 2016b). In situations of conflict and repression, minority group boundaries generally become more salient, reinforcing within-group loyalty and altruism (Flanigan et al. 2015, p. 1793). This can affect the impartial delivery of aid, as CSOs are caught in their own web of 'ethnic proximity, socio-political affiliation or local pressure' (Zyck and Krebs 2015, p. 3). However, local embeddedness also generates the ties of trust with communities necessary for aid operations' 'access, cover and legitimacy' (Wallis and Jacquet 2011).

Desaine (2011, p. 8) explains the prevalence of CSOs in ethnic States and among minority religions, noting that they are 'most likely to find operational space in marginal areas, where the Bamar prevailing state and its symbols have less presence'. Myanmar CSOs rely upon three major social navigation strategies. The first is the long-term decision making that shapes an organisation's pedigree: operating from outside or inside the country, and more or less formally (Desaine 2011). Some organisations balance formalisation's advantages (e.g. ability to receive international funding as a registered LNGO) and disadvantages (e.g. obligation to submit programmes and budgets to the government) by engaging in partnerships. For example, CSOs not registered as LNGOs can retain independence and flexibility while also accessing (Western) funds and a legal framework via participation in larger national or international umbrella organisations (Wallis and Jacquet 2011). Second, on a case-by-case basis, civil society actors adapt 'their terminology, their visibility, and sometimes their actual activities to the limitations posed by central and local authorities' (Matelski 2016b, p. 178-179). How this is done depends on the 'the context of the moment, connections with/ protection from the government, location and degree of sensitivity of the work' (Desaine 2011, p. 19). Third, at a broader all-compassing level, civil society actors are well versed in the 'politics of silence', influencing decisions not through direct confrontation, but by 'remaining low profile' (Desaine 2011, p. 7).

\section{International humanitarian actors}

International humanitarian actors add to the complexity of governance (Hilhorst 2016). In Myanmar, the 'decade-long conflict over the legitimacy of competing socio-political and armed actors' intermingles with 'the evolving agendas and priorities of international players' through 'politics, money, and power' (Décobert 2016, p. 
6). These factors play out, for instance, when authoritarian states refuse international assistance, as initially occurred when Cyclone Nargis devastated Myanmar in 2008 (Alles 2012; Selth 2008). Paik (2011) details how authoritarian regimes balance political need and risk regarding accepting foreign aid and, if accepted, the degree of government control exerted over the movement of foreign aid workers and resources. In the Nargis response, foreign aid was eventually allowed 'selectively and reluctantly' and was mostly distributed via government channels; Western rescue and medical staff and many vessels carrying relief goods were turned away at Myanmar's border (Paik 2011, pp. 450, 455).

International actors ranging from the United Nations (UN) to INGOs have long been reticent to take a stand on governments' treatment of minorities (Fortman 2006, p. 35). Taking such a stand in regimes that perceive cultural heterogeneity as a threat to political unity and stability would be especially likely to raise tensions (Koenig and de Guchteneire 2007). The move towards a multicultural understanding of the nation-state and the emergence of an international human rights regime led to new repertoires of contention and claim making, enabling humanitarian actors and other governments to legitimately challenge national governments (Koenig and Guchteneire 2007). Still, engaging on minority issues can be a double-edged sword. Referring to Myanmar, Taylor (1982, p. 7) argues that 'ethnic politics is the obverse of the politics of national unity' when conflicts around socioeconomic issues are increasingly framed as ethnic.

The new repertoires of contention and claim making regarding minorities have hardly permeated disaster-related policy and practice. Disaster practitioners still portray themselves as apolitical and technical-partly to facilitate access and operations (Peters 2017). Harvey (2013) asserts that, although humanitarians often take cover behind humanitarian principles to avoid engaging with states in conflict settings, an increasing number of frameworks and guidelines codify humanitarian-state engagement following disasters. Disaster policy mentions a need to focus on the most vulnerable or marginalised and indigenous populations. ${ }^{4}$ However, demands such as the inclusion of indigenous knowledge in disaster risk reduction and response programmes are mostly apolitical, based on a romanticised depiction of indigenous peoples as interwoven with nature (Hilhorst et al. 2015). Issues such as exploitation or rights violations, which can contribute to disaster vulnerability and marginalisation during the response, are largely neglected.

It is uncertain how similar social navigation options are for international humanitarians and civil society actors. In the authoritarian contexts of Uzbekistan and Turkmenistan, del Valle and Healy (2013, p. 189) concluded that, for MSF, 'successful access negotiations hinged heavily on demonstrating added value (medical relevance) while simultaneously building relationships with authorities [...] and hoping that such measures could promote a level of acceptance or trust needed to operate'. One would expect international humanitarians' navigation routes to be more limited, given the ability of authorities to control 'external agents' through visas, travel authorisations and other procedures. The steady trend towards the rationalisation and coordination of humanitarian action since the 1990s can also limit options (Duffield 1997). Today, standards and blueprint institutional structures are largely applied across countries. Aiming to increase transparency and accountability, the standardisation 'largely reflect $[\mathrm{s}]$ the concerns, priorities and values of technical professionals in Northern agencies'; this leaves little room for co-shaping programmes with in-country humanitarian partners or adapting to complex humanitarian situations (Dufour et al. 2004, p. 124). Although INGOs often choose to fit into this 'standardised' humanitarian system, many remain more flexible regarding funding and decision making (Davey et al. 2013; Lyons 2014).

In Myanmar, prior to the democratisation process starting in 2011, international actors were known for a fixed, polarised stance in an 'internationalised battle of legitimacies', either judging it more effective to engage constructively with the government or preferring to operate cross-border, informally and/or via CSOs (Décobert 2016, p. 8; Duffield 2008). Desaine (2011) argues that international actors perceived LNGOs as systematically opposed to the (semi-)military regime and always on the side of good. It remains to be seen how these dynamics had evolved by 2015 .

\section{Methods}

The present article is based on primary data I collected during a 4-month period (September 2017-February 2018) in Yangon and Chin State. During the fieldwork, restrictions and intense violence described by the $\mathrm{UN}$ as 'very likely' ethnic cleansing of the Rohingya (Trihartono 2018, p. 7; UN 2018, p. 8) made access to Rakhine impossible and increased distrust towards outsiders interested in humanitarian issues. This also hampered access to some Yangon-based organisations deeply involved in the crisis, especially those I suspected of relying on more 'informal' methods. However, disaster response processes could be reconstructed through conversations with approachable Yangon-based practitioners who had been directly involved in the 2015 cyclone response in Rakhine and/or Chin State as decision makers based in offices or on the ground. A 10-day trip to Hakha, the landslide-impacted capital of Chin State, allowed direct observation and interaction with actors in a minority 
area. The trip was largely spent with Hakha community members who had been displaced since 2015, CBO and LNGO employees, and INGO staff members who were involved in the 2015 response from their Asian regional headquarters.

The data collection involved documented exchanges with a total of 71 participants, 46 of whom participated in in-depth semi-structured interviews or focus group discussions. Interview participants were selected from key organisations involved in the 2015 response, as determined based on grey literature and referral sampling. The data collection focused on perceived marginalisation, challenges and strategies developed during the 2015 Komen response in Chin and Rakhine States, specifically in the strongly disaster-impacted townships of Hakha (the Chin State capital) and north of Sittwe (the Rakhine State capital) (outlined in blue in Fig. 1). Although some depth is lost by detailing processes in two areas instead of one, the comparison highlights the diversity of LIC and minority dynamics within a single-country context and enables a differentiated and layered account of social navigation strategies.

As shown in Table 1, I aimed to engage with a large variety of non-governmental actors. For instance, for civil society actors, I approached members of more and less formalised organisations (LNGOs vs. CBOs), including those positioned closer to either international or ethnic/religious networks and those claiming to have a bridging role. During the Yangon-based interviews, trust and deeper insight were attained as respondents first discussed less sensitive Chin State dynamics and then contrasted these with those in Rakhine. Additional data were collected from secondary sources (press clippings, humanitarian and CSO reports used for lobbying), through everyday observation and from casual conversations (e.g. during formal CSO meetings in Hakha and informal dinner discussions with humanitarian actors in Yangon). All data were stored using NVivo and analysed using both pre-determined codes and codes derived through a thematic analytical process (Braun and Clarke 2006).

Several fieldwork limitations affected the conclusions that could be drawn. The 2017 escalation of tensions and violence among community groups and between humanitarian actors and the government may have influenced respondents' recollection of 2015 dynamics. The one interview with a government representative, who mostly recited government policies and questioned the rationale of my research and presence in Myanmar, indicated that minorities and even humanitarian support were topics too sensitive to discuss with such officials. Furthermore, the data certainly reflect respondents'

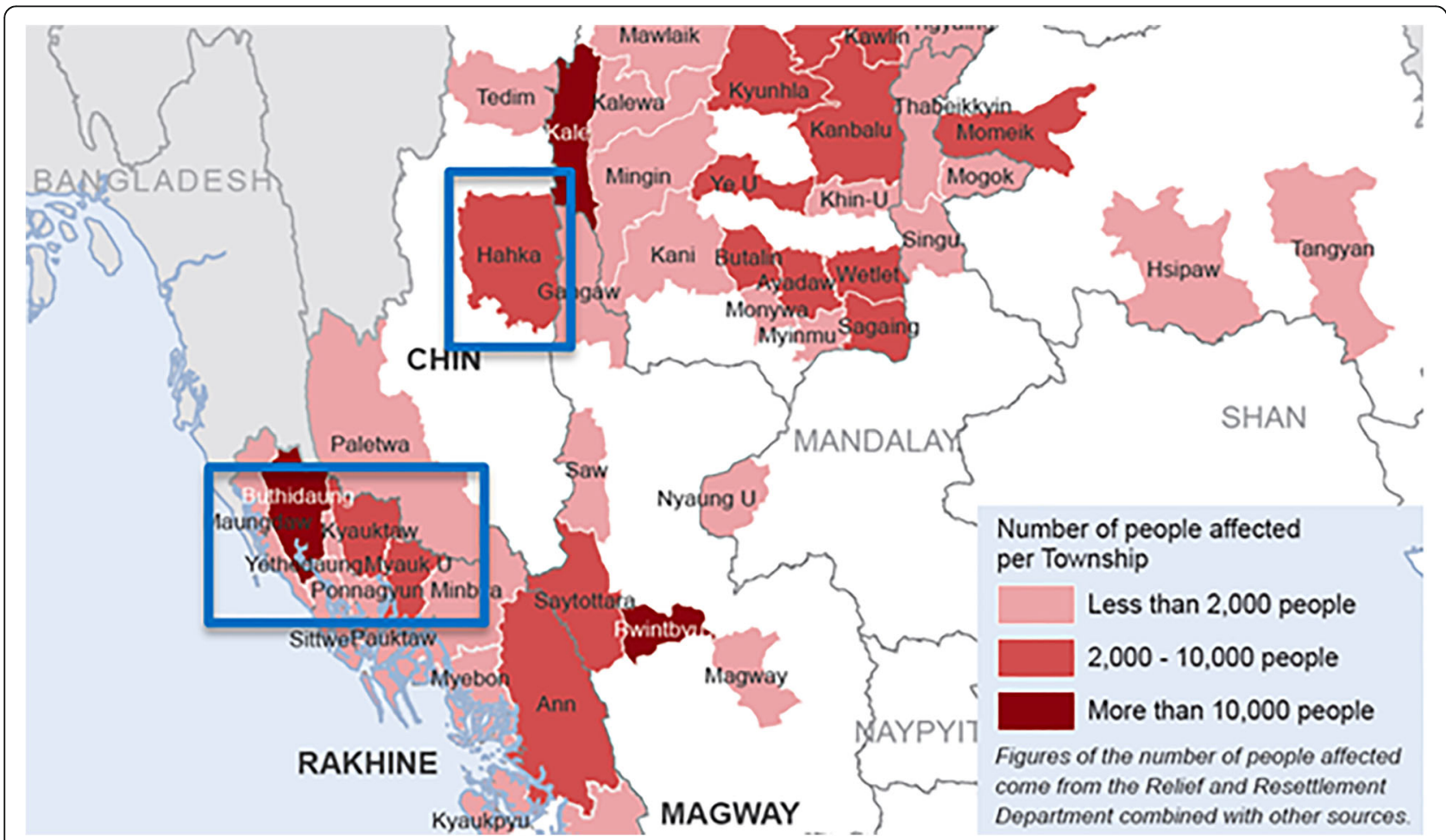

Fig. 1 Case study areas and 2015 flood-affected townships. Case study areas (framed in blue) and flood-affected areas compiled based on government and humanitarian sources on 3 August 2015 (in red). Source: modified based on UN Office for the Coordination of Humanitarian Affairs $2015 b$ 
Table 1 Overview of interviewees and focus group participants

\begin{tabular}{lll}
\hline Actor type & & Number of participants $^{*}$ \\
\hline Civil society disaster response actors & Community-based organisations & 4 \\
& Local non-governmental organisations & 7 \\
International humanitarian actors & International non-governmental organisations & 9 \\
& International organisations such as UN agencies & 4 \\
& Humanitarian donors & 1 \\
Other & Independent consultant & 1 \\
& Chin State government official & 4 \\
Total & Academics, local and foreign & 10 \\
Natidents displaced by the 2015 Hakha landslide & 47
\end{tabular}

"Participant numbers refer to in-depth interviews, except for displaced residents, who participated in focus groups

personal trajectories. For example, statements on marginalisation must be treated with caution in a context where memories of human rights violations are still fresh. Acknowledgement of relief coming from the government or military was rarely unprompted and often given grudgingly, as is reflected in a statement made by a Hakha resident during a focus group (\#8, 22 November 2017) $)^{5}$ : 'Yes, the army provided tar for the road reconstruction. But leave the military out of it. I don't even want their money'.

In line with the epistemological paradigm of critical realism and the interpretive approach (Summer and Tribe 2008, p. 58), the subjectivity of framings and divergences among them are part of my findings and reflective of the broader LIC dynamics at play.

\section{Context}

In 2015, Myanmar experienced heavy monsoon rains, and cyclone Komen triggered landslides and the most widespread flooding in decades, leaving 125 dead and 1,676,086 temporarily displaced (UN Office for the Coordination of Humanitarian Affairs 2015a, 2015b). Cyclone Komen made landfall at a time of heightened Myanmar identity politics - a few months after four discriminatory 'Race and Religion' laws were passed and a few months before the tense November 2015 elections.

In the broader context, a triple transition increased volatility and uncertainty for minorities, CSOs and international humanitarian actors. First, anti-minority and especially anti-Muslim attitudes rose to a level of explosive hatred and vengeance, not least on social media (Kipgen 2013; Wade 2017). Second, the partial democratic transition multiplied the institutional entry points among military and civilian institutions, both of which are present from the highest governance level, the Union government, to the township level (Sifton 2014). Third, the Myanmar aid system was overhauled. Myanmar jumped from lowest international aid beneficiary per capita in the region, with close to no aid going through the government (Kang 2012, p. 352), to 'donor' darling status with the establishment of UN sectors, clusters, and permanent donor and INGO headquarters (Décobert 2016, p. 63). For the first time, the Myanmar Union government officially appealed to international cyclone support on 4 August 2015. The government then worked with staff dispatched from the United States' Federal Emergency Management Agency in the newly operational Crisis Management Unit in Myanmar's capital of Nay Pyi Daw.

Not all local structures benefitted from the exponential increase in international donor interest following Nargis and the 2011 political liberalisation process. Civil society actors had gained legitimacy following their mobilisation as sometimes sole responders to cyclone Nargis in 2008 (Desaine 2011; Selth 2008; South et al. 2011). Thousands of informal CSOs emerged, some officially registering as LNGOs when the process was facilitated in 2014 (LNGO\#13, 22 January 2018). Matelski (2016a, p. 117) highlights how Western funding has mostly reached state actors and the limited LNGOs considered sufficiently 'professional' and supportive of Western interests.

Chin and Rakhine were the only two ethnic States declared disaster-affected zones by the Myanmar Union government because floods and landslides surpassed local response capacities (Zaw and Lim 2017, p. 2). Disaster impacts, LIC/minority tensions and humanitarian dynamics varied greatly between the two states.

\section{Chin State}

Bordering Rakhine State to the east and India to the north, Chin State was strongly hit by the 2015 floods but especially the landslides, which swept away fields, roads and bridges in mountainous areas. The Myanmar National Natural Disaster Management Committee (2015a) identified Hakha township as one of the five most 
affected townships nationwide. In Hakha town, entire neighbourhoods were wiped out, affecting 6535 and displacing more than 4254, according to a CBO assessment (Chin Committee for Emergency Response and Rehabilitation [CCERR] 2015, p. 11).

The Chin are a predominantly Christian religious group and have faced persecution in Myanmar. In Chin State, 'the military has been accused of the destruction of churches and Christian symbols, of forced conversion to Buddhism, and of killing several Christian leaders' (Sakhong 2007, cited in Matelski 2016b, p. 65). Today, Chin State is considered the poorest and most remote State in Myanmar ${ }^{6}$ (UN Development Programme 2011). The 'state-subject relationship between the Chins and the Bamar state' has historically been distant (Mark 2016, p. 142). At the 2013 Chin National Conference, Chin political and civil society actors called for a stronger role for state government, involvement and consent of indigenous/ethnic minority groups, transparency and accountability, and more Chin political representation at Union level (Mark 2016, p. 153).

There is division among more than 50 different Chin ethnic sub-groups belonging to different Christian church denominations and in rarer cases also Animist faith (Desaine 2011, p. 36). Little presence of IOs and INGOs in this remote area is partly offset by extensive, mostly Christian, diaspora networks spanning the globe. Linkages among Chin communities and international Christian churches, Western advocacy groups and INGOs are strong, building on a tradition of British missionary and educational work and the colonial British preference to work with Christian organisations (Desaine 2011; Matelski 2016a, p. 95). In Myanmar, Christian organisations appear more visible compared with Buddhist organisations (Desaine 2011, p. 13), and Christians are generally over-represented in CSOs (Heidel 2006).

\section{Rakhine State}

As the most western and coastal State of Myanmar, Rakhine was hit first when cyclone Komen made landfall on 31 July 2015. Strong winds and rains caused landslides and extensive flooding in eight townships, with 125,151 houses damaged and 217,246 acres of arable land destroyed. As of 4 September 2015, 96,165 inhabitants of Rakhine State were still displaced (National Natural Disaster Management Committee 2015b).

The five townships situated north of the State capital of Sittwe were also the theatre of the 2012 intercommunal violence that killed hundreds and displaced 140,000. Detailing the historical and politico-military context of the Rakhine border with Bangladesh, Farzana (2015, p. 296) refers to the area as in 'continual disorder' since the 1784 local rebellion against Burmese invasion. ${ }^{7}$ In 2015, tensions were high among diverse ethnic and religious groups: Buddhists of sometimes Bamar but predominantly Rakhine ethnicity; socioeconomically weaker Muslims, historically deprived of economic opportunities and of 'political rights and opportunity of service in the government, ministries, directorates, departments, corporations, judiciary, education and local administrative councils' (Parnini 2013, p. 286); and other minorities lacking political representation. The last group included a few thousand Rakhine residents of Chin ethnicity (CCERR 2015). The approximately one million Rakhine-based Rohingya are among the most marginalised minorities in Southeast Asia. They have faced intense human rights violations at the hands of the population and the Myanmar military (Farzana 2015; Kipgen 2013). When cyclone Komen struck, 140,000 Rohingya were still housed in camps for internally displaced persons (IDPs) (European Civil Protection and Humanitarian Aid Operations 2015).

Together with conflict-ridden Kachin, northern Rakhine State has the highest presence of international humanitarian actors outside of Yangon. A few international organisations have carried out cross-border operations since the 1980s, but not without challenges. MSF France decided to withdraw from the region and country in 2004, as changing regulations hampered organisations' freedom of movement and work. That same year, the International Committee of the Red Cross was forced to suspend activities (Currie 2012, p. 26; International Crisis Group 2006, p. 8). An international Rakhine humanitarian cluster was established in Sittwe after violence flared up in 2012, also impacting the Western staff of international humanitarian organisations. Many aid organisations chose to call their Western staff back from Rakhine to minimise safety risks or were forced to leave by the government, as was the case for MSF Holland (Matelski 2016b, p. 243). The Organisation for Islamic Cooperation was never authorised to provide post-2012 support in Myanmar-a decision backed by Buddhist demonstrators (British Broadcasting Corporation 2012). Accusations of bias from residents of Rakhine ethnicity towards 'Western organisations' were not unfounded. The CDA Collaborative Learning Projects (2009, p. 10) highlight how the Rohingya were 'considerably more likely' to receive support from INGOs and IOs, whereas Buddhist ethnic Rakhines were more likely to receive support from the government. This report thus concluded that foreign aid played into the local conflict dynamics. Concerning civil society actors, Desaine (2011, p. 38) mentions a void of LNGOs in northern Rakhine and an increasing presence of LNGOs 'based on Buddhist charitable pillars' in southern Rakhine.

\section{Findings}

For both States, this section details (i) how respondents perceived minorities to be marginalised in the 
government response and the disaster response of (ii) civil society and (iii) international actors, including the challenges they faced. Social navigation strategies are also presented for the actor group most instrumental in providing relief to minorities.

\section{Chin state}

\section{A marginalising government response?}

Community respondents and civil society actors approached in Hakha and Yangon accused the Union government of neglect, in both interviews and official publications. One report issued by a CBO (CCERR 2015) argued that, although Chin State is the poorest in Myanmar and among the hardest hit by the 2015 floods and landslides, only $4 \%$ of Myanmar Union flood relief funding went to the state. Additionally, the state government's coordination efforts, which were described as corrupt, following the whims of the Union capital and mostly employing non-Chins, were deemed late and disappointing. In Hakha, government relief reportedly reached only 2000-3000 people; there was a 'difference in thousands' between the counts of people impacted provided by the General Administration Department and by CBOs and LNGOs (LNGO\#2, 23 November 2017). One CBO respondent (\#2, 17 January 2018) stressed that government control is only problematic when the response deviates from the 'moral contract' of fair and transparent aid distribution. In Hakha, poorer households, for instance, did not qualify for governmental disaster support because they did not live in formally registered housing. Furthermore, Union government relief shipped to government warehouses was not distributed to victims (LNGO\#2, 23 November 2017; CBO\#3, 23 November 2017). In September 2018, a CBO statement publically denounced the wasting of aid and the General Administration Department keeping the remaining disaster relief funds (CCERR 2018).

Respondents debated whether the discrepancy between actual needs and what the government provided was caused only by logistical difficulties of getting aid to the remote Chin mountains, where there was no airport and roads had been destroyed by the storm-as advanced by several humanitarians and the government official (\#1, 23 November 2017)—or whether this discrepancy was also a manifestation of the 'double $\mathrm{C}$ curse', reflecting marginalisation for being Chin and Christian. The latter explanation was supported by all Chin respondents and by Burmese non-Chin INGO representatives. According to a Chin-based LNGO representative (\#14, 19 January 2018), 'some say there was discrimination [and] that government response was limited because we are Christians. The government said in the news [that] they were giving out bags of rice, but that was only in the news'.

\section{A thin international response}

The above accusations of marginalisation were dismissed by a few foreign respondents, including one who had worked for a Chin LNGO (\#2, 25 October 2017). Yangon-based humanitarians operating country-wide emphasised that responding in Chin State was not the highest priority and was very difficult logistically (IO\#3, 7 November 2017). Only actors with a permanent presence in Hakha (a few larger IOs and one INGO) provided direct support, mainly in government-regulated IDP camps. Their support through hygiene, education and non-food items was welcomed by Chin-based LNGOs, CBOs and residents. A representative of a Christian INGO that channelled funds through like-minded faith-based LNGOs recounted difficulties in obtaining travel authorisations from the Union government for monitoring visits (INGO\#2, 20 November 2017).

\section{An overwhelmingly civil society response for minorities}

Internationally funded Christian LNGOs, and especially $\mathrm{CBOs}$, were the primary responders. One LNGO director (\#2, 23 November 2017) reported channelling some of their funding to a $\mathrm{CBO}$ because they had 'lots of connections and cooperate with civil society'. There were rumours that funds sourced through the Chin diaspora and Christian networks surpassed the government's relief budget, but it proved difficult to obtain the exact numbers.

However substantial, the civil society response should not be romanticised. Several CSO respondents accused major Hakha-based CBO networks of lacking accountability and channelling resources to their own ethnic sub-groups, churches or geographical areas. This was stated in two independent focus group discussions with displaced Hakha residents. Among many examples, residents recounted how a Hakha-based Christian association used donations to buy buses for their own use (resident\#6, 22 November 2017). They were particularly disappointed with a locally established committee founded to coordinate the civil society response in Hakha, which had, they felt, mismanaged the process:

They only gave materials later, when they were rotten. Decaying. We only got one-third of the donated materials. [...] They only recently publicised how much money they collected, but it was not clear where that went, and we could not ask any questions. (resident\#3, 22 November 2017)

Few strict governmental restrictions seemed to apply to CBOs: many had not registered as organisations until months after the initial relief phase. Still, CSOs faced three main challenges: everyday delays and blockages 
caused by government authorities, difficulties in mobilising international aid funds and the risk of increasing tensions over aid distribution decisions.

Concerning the first challenge, civil society actors accused the government of hampering their initiatives. CBOs not fulfilling specific criteria were initially excluded from emergency meetings coordinated by the state government, until it became clear how much funding civil society could contribute (LNGO\#2, 23 November 2017). Additional examples illustrate authorities' power to block, delay or raise the costs of relief activities for Chin State. Aid supplies from the Royal Thai Air Force were diverted to a Bamar-dominated area outside of Chin State by the Union government (CBO\#2, 17 January 2018). Additionally, as relief goods collected by the Chin diaspora transited through Yangon airport, the Union government levied high taxes, searched the goods and kept them in customs for 2 weeks (LNGO\#14, 19 January 2018).

Second, CBOs and LNGOs without ties to Christian INGOs reported difficulty mobilising funding through the newly 'rationalised' humanitarian system. CSOs previously had privileged relations with their 'own traditional donors, INGOs which [they] worked closely with', but they now had to 'rely more and more on institutional donors' with intensive procedures and requirements. This was described by all LNGOs and even international aid actors with longer experience in the country as hampering responses that were, in the words of one LNGO representative, 'quick, flexible' and sometimes also 'conflict-sensitive' (\#6, 10 January 2018). According to a CBO representative (\#2, 21 November 2017), the UN agencies they hoped to engage with judged them as too blunt on the topic of minority marginalisation: 'The $[\mathrm{IO}]$ once told us $[\ldots]$, do not talk so critical [or else] people will hate you and you will not succeed. Try to be positive. But a CSO's role is to make noise'. The CBO wished to advocate for more minority support, but that was perceived as biased by the humanitarians.

Third, distributing relief without raising tensions among the more than 50 different sub-ethnic and religious groups was considered challenging. An LNGO director (\#14, 19 January 2018) often had to counter accusations of ethnic bias because her organisation was named after her area of origin. A CBO representative (\#2, 17 January 2018) accused faith-based groups of using the distribution of Chin diaspora funds for evangelisation, especially in southern Chin, where Christian, Buddhist and Animist groups coexist.

Civil society actors' navigation strategies Civil society actors chose from or combined two main routes to navigate the above challenges: activating minority networks and trying to play the government and the internationally led relief system.

Civil society strategy 1: Activating minority networks Large amounts of funding and supplies came from neighbouring areas with similar minority backgrounds, far from Nay Pyi Daw and Yangon, the power centres of the Union government and the international humanitarian system. Cars transporting relief goods donated by the predominantly Christian Indian state of Mizoram and the Kachin 'brothers and sisters' which share a similar ethnic background are not 'illegal' per se, but lie within a 'grey zone' of informal practice. As put by a Hakha resident, they 'tasted Indian rice first', before supplies from Nay Pyi Daw reached them, if they ever did (\#4, 22 November 2017). To minimise tensions among the different Chin ethnic sub-groups, the Kachin group channelling resources asked for those resources to be divided equally among all Chin townships. A CBO actor (\#2, 23 November 2017) criticised this practice, claiming it was unfair to the most affected townships.

Charismatic individuals and their personal networks were instrumental in mobilising funds outside the formal humanitarian system. For instance, one donor (\#4, 1 February 2018) reported how a CBO bypassed his organisation to receive funding directly from his governments' national treasury, using existing ties between a respected Chin individual and a parliamentarian in that foreign country. Less attached to regulations and conditions, this funding could quickly reach Chin communities. Another case involved a Chin LNGO leader (\#14, 19 January 2018) who used a trip to attend a wedding in the United States for fundraising in churches and Chin diaspora communities, raising thousands of United States dollars.

Civil society actors also lobbied via the diaspora press, deemed more independent than the in-country press (LNGO\#2, 23 November 2017). Chin actors generated their own evidence to question the validity of the government and humanitarian disaster response. A Chin-based CBO (\#2, 17 January 2018) collected data on disaster impacts and response, co-forming an extensive network of data collection partners across communities.

\section{Civil society strategy 2: Playing the humanitarian} system The results of the community impact assessment introduced at the end of the previous paragraph were presented at Yangon press conferences and a Nay Pyi Daw Humanitarian Country Team meeting. This demonstrates the extent of time and energy devoted to lobbying humanitarian decision makers, who control growing amounts of aid funding. These decision makers can also 'validate' and 'legitimate' minorities' plight by directing funds to them. International actors seemed to notice these efforts; several humanitarians referred to 
Chin CSOs as 'vocal' and 'mobilised in complaining' (e.g. IO\#3, 7 November 2017).

Whom to approach with what information and how to do this were carefully considered. Sometimes, approached actors' follow-up moves were predicted in a chess-like manner. The question of why the above Chin-based CBO did not directly lobby Nay Pyi Daw authorities with their report yielded an intricate answer:

The government makes the decision but especially the UN provides them with information and support [through] resources. We cannot approach the government so much, so we go via the UN. In the end, the government decides. So we constantly observe the government - what they do, what happens. The UN can influence the government [...] They took our data. We showed them our community data and the government data, and the difference between both. (CBO\#2, 17 January 2018)

The abovementioned report included detailed comparative tables, graphs and 'lots of footnotes for the donors' (academic\#1, who edited the report, 6 November 2017). Speaking the language of the humanitarian system was a strategy for playing this system. CSOs strategically self-branded and adapted their discourse to suit their targets. For example, one CBO (\#2, 17 January 2018) spelled out the ' $\mathrm{C}$ ' in their organisational acronym as 'Chin' or 'Community', depending on whether they were engaging with the Chin diaspora or the UN. Taking self-framing to the individual level, an INGO official (\#9, 5 January 2018) of Chin ethnicity but with a Bamar-sounding name reported disclosing her ethnic origin only when it was advantageous.

CBOs strategically appealed to allies who could help them reach international audiences, such as the United States academic who helped compile the Chin community data report or the 'good influential UN guy' who could be 'grab[bed]' to lobby in high-level humanitarian meetings (CBO\#2, 17 January 2018). I met several 'free-floating' foreigners who brokered linkages between civil society and international actors.

\section{Rakhine State}

\section{A marginalising government response}

Similar to the situation in Chin State, the $14.7 \%$ of Union relief funds allocated to Rakhine State was deemed insufficient given the large-scale coastal devastation (CBO\#2, 17 January 2018). Statements made in interviews and in print (e.g. CCERR 2015; ECHO 2015) identified additional intra-state marginalisation in the government response. First, locally powerful people such as township administrators channelled aid towards their own non-minority community groups (CBO\#2, 17
January 2018; donor\#3, 29 January 2018). Second, relief modalities that might have been unproblematic in less-divided settings further marginalised minorities. For instance, relief cash grants ended up in the hands of the local market owners, government regulations forbade Muslim contractors from participating in public infrastructure reconstruction, and government and sometimes IO relief was distributed from monasteries, limiting non-Buddhists' access (donor\#4, 1 February 2018; CBO\#2, 17 February 2018). Third, isolated cases of severe minority marginalisation were reported. For example, an IO official (\#5, 11 January 2018) mentioned that the relocation of Muslim flood victims in 'military vehicles' was 'not always done voluntarily'.

\section{A thin civil society response for the most marginalised minorities}

Another layer of marginalisation was obstruction of self-help and local relief initiatives' for minorities. Marginalised and vulnerable minorities had less capacity to cope and self-organise because of their lower economic and social position and limited rights. Rohingya disaster victims in government IDP camps denied freedom of movement are an extreme example (ECHO 2015).

Concerning $\mathrm{CBO}$ and LNGO support to Muslim groups, and especially to the Rohingya, organisations with Muslim ties were not allowed to operate. I could find only one Muslim faith-based organisation, operating in an IDP camp without a formal memorandum of understanding (MoU). The government would not provide a MoU, but the group felt that operating under such conditions yielded certain advantages: flexibility, reactivity, the ability to spend funds received from mostly Muslim (sometimes diaspora) philanthropists worldwide in a timely way, and less scrutiny-as long as their privileged relationship with the local authorities continued and the government saw benefit in having a 'token Muslim organisation' operating (INGO\#1, 10 October 2017).

CSOs without Muslim ties were largely unwilling to assist Muslims. Several INGOs, IOs and donors who would have liked to dispatch aid via local implementing partners described Rakhine-based CBOs and LNGOs as 'not principled'. One INGO representative (\#17, 23 January 2017) stated, 'I prefer a localised response, but this context really needs the international hand to make sure the vulnerable people are targeted'. Indeed, of all the CSOs I approached, only one staff member of a Chin-based CBO primarily supporting Rakhine residents of Chin ethnicity said that she personally would have liked to also support Muslims including the Rohingya, but that it was too risky for her organisation: 
We speak on behalf of other minority groups. But with Muslims it is tricky on the ground [...] Even if I personally also feel for the Rohingya. But if you are in a dangerous situation [...] Between the tiger and the snake, you have to be careful. Limits exist even for [our organisation]. (CBO\#2, 17 November 2017)

\section{An overwhelmingly international response for the most marginalised minorities}

Assistance for Muslim groups, the most marginalised minorities in Rakhine, was generally international. International humanitarian actors faced four broad challenges: stigmatisation and security risks, government control, uncertainty, and manipulation.

At organisational and individual staff levels, disaster responders feared stigmatisation and security repercussions of supporting Rakhine Muslims after the 2015 disasters, as an IO representative mentioned: 'In Rakhine, everyone is poor. It is true the Muslims are often worse off, but working only for them is a suicide mission' (IO\#10, 30 January 2018). One INGO representative (\#17, 23 January 2018) described how the movement of every aid convoy passing through host communities and any effort to resettle Rohingya groups somewhere with better facilities were scrutinised, including by non-Rohingya Muslim communities. Agencies providing relief to Muslims were criticised in public demonstrations and on social media, sometimes including the names and photos of staff members, who were labelled 'terrorists' for helping 'Muslim terrorists'. In this context, the figure of the 'inpat' emerged: Burmese INGO or IO staff members who had outsider status and faced stigmatisation from their own community for supporting an ethnic or religious group other than their own in a LIC-divided society.

Concerning engagement with government structures, several respondents mentioned government restrictions or conditions they had to satisfy, such as the impossibility of working with 'non-citizen' Rohingya disaster volunteers or staff (INGO\#16, 21 January 2018) and limited access to Rohingya IDP camps (INGO\#1, 10 October 2017). International humanitarian actors depend on various government authorities for permits, MoUs for programme activities and travel authorisations. $\mathrm{Hu}$ manitarians deemed it dangerous to denounce their lack of independence. An INGO official (\#17, 22 January 2018) admitted that 'our organisation is usually a loud organisation [...] but here we never participate in a shout'.

Uncertainty about navigating complex government structures also emerged. Many foreign aid workers described feeling 'overwhelmed' by everything being in transition. Some regulations continued, such as getting authorisation from the village tract authorities, which are part of the military-led General Administration Department. However, with the political transition, entry points multiplied, calling for 'lots of negotiations, all the time, with a lot of different dynamics' (IO\#2, 10 October 2018). Authorities under central civilian and military leadership and parallel ethnic State and Union structures operate at different governance levels, often without communicating with each other-for instance about authorisations granted to humanitarian actors. Government authorities operate informally and unpredictably, failing to record agreements (donor\#4, 1 February 2018) and switching travel authorisations on and off, thus hampering planning (INGO\#4, 18 October 2017). Organisations' assessments of how the political transition impacted their room for manoeuvre differed, and, as is shown in the following extract from a Burmese staff member of an INGO with a broader mandate, they criticised organisations with different approaches:

Some humanitarian actors here act as if nothing has changed. They still think the military is in control. They hide some of their activities. They lie. We are honest. We have nothing to hide, and it works. (\#11, 10 January 2018)

Finally, several respondents described the government's 'double game'. Officially, the authorities were not receptive to demands for more minority support. The Rohingya's very identity is negated in government discourse, where their name is never mentioned. However, behind the scenes, authorities pushed IOs and INGOs to cater to Muslims only. An IO official characterised this as a political manipulation tactic:

So often the government says 'No, no, we will be giving to the Rakhine community. And you do it for the Muslim community'. That was the big issue from the beginning. We are then perceived as the bad [...] Nobody in this country is interested in [being well perceived] by the Rohingya. They do not count. It is not an audience [anyone is] interested in. They are interested in communicating the message that they take care of the Rakhine, and mostly the Bamar [...] So it is a political manipulation. (IO\#3, 7 November 2017)

Manipulating international humanitarian actors to help only Muslims dates back at least to the 2012 intercommunal violence. After organisations asked to help both Buddhist and Muslim victims, 'the government said ok to both, but granted authorisation for helping the Muslims first, and the other [authorisation] never came' (donor\#4, 1 February 2018). 
International actors' navigation strategies The strategies of two outlier disaster responders active in Rakhine (the $\mathrm{CBO}$ channelling relief mainly towards Chins through ethnic and religious networks and the Muslim INGO operating without a $\mathrm{MoU}$ ) were detailed above. Otherwise, international humanitarians described four main strategies for navigating Rakhine-specific challenges: targeting choices, perception management, approaching and distancing themselves from other actors, and financial incentives to involve CSOs.

International strategy 1: Setting a course via targeting In the LIC setting of Rakhine, selecting disaster victims to help (i.e. targeting) was presented as key to humanitarians' acceptance by host communities and the wider public, although the choice is not the organisation's alone, as the above statements concerning government manipulation highlighted. Two opposing logics stood out and are here referred to using the terminology commonly used by the respondents: '50/50' vs. 'needs-based'.

Each respondent framed her/his organisation's targeting strategy as the most conflict-sensitive. Often, the strategy also fit the organisation's pedigree. The '50/50' strategy meant providing exactly the same amount of the same goods to antagonistic community groups, regardless of need. This was considered the only viable solution by many respondents but was dismissed as the 50/50 trap' (e.g. IO\#10, 30 January 2018) by others. Likewise, the 'needs-based approach', which refers to the humanitarian principle of impartiality, was defended by some respondents and discarded as 'utterly naïve' in the tense context by others.

International strategy 2: Hoisting the right flags Not only what an actor does (e.g. their targeting strategy), but also how their actions are perceived by various antagonistic audiences, is important: 'It is about [perception] balances. Of course, at the next level, tensions are also manipulated' (INGO\#17, 22 January 2018). A few respondents criticised perception management sometimes taking precedence over intrinsic activity rationales: 'Some do activities to gain acceptance. Ok, let's get acceptance. What can we do?' (IO\#10, 30 January 2018).

All respondents closely monitored the views circulating about their organisation and relief activities. That was especially the case on social media, where stories can rapidly be distorted and go viral. One such story was the 'mosque story': An IO (\#10, 30 January 2018) discovered that it was being harshly criticised online for 'funding mosques' in Rakhine as part of the response. The IO immediately dispatched field staff, finding that 'village elders had asked each cash grant beneficiary to give $10 \%$ [of their grant] for the mosque reconstruction. We went back and explained to them that this is not [how the funds should be used] [...] [To prevent such situations], you have to be proactive concerning rumours and allegations [...] It can quickly turn against you'.

In addition to close monitoring, actors dedicated significant effort to self-framing and communicating about their relief work in the field, in print and online. One $\mathrm{IO}^{8}$ asked for its logo to be removed from the UN multi-actor flood relief overview map, as it did not want to be associated with the domestically unpopular UN. A donor (\#4, 1 February 2018), despite agreeing overall that it was disadvantageous to be visible in northern Rakhine, thought it would benefit his organisation to foreground flood relief activities through a one-page report, local media and a press release. Larger INGOs and IOs all have visibility guidelines ${ }^{9}$, and two important donors (\#3, 24 January 2018; \#4, 1 February 2018) highlighted perception management as a core discussion point with the agencies they funded.

Concerning the Rohingya, international organisations learned to mirror the language of authorities, sometimes compromising on their own principles:

In 2015, we did not use the term 'Rohingya' [...] If you want to have a conversation at all, you should use the same terms as the government, ['Muslims' or 'Bengalis'] [...] We consistently support the right of self-identification, but in terms of relationship[s] with authorities [...], if you actually want to achieve something, do not say 'Rohingya'. (donor\#4, 1 February 2018)

Myanmar staff members were considered better versed at adapting their behaviour and discourse. An IO staff member thus reported that, to negotiate with authorities, they 'usually send the Myanmar staff; they know how to deal with authorities, with the strong state' (IO\#10, 30 January 2018).

International strategy 3: Navigating the actor constellation Organisations with broader mandates including development or policy work presented their organisational pedigree as beneficial to relief operations. Long-term engagement with members of parliament (INGO\#11, 10 November 2017) or with Rakhine fishers (donor \#4, 1 February 2018) resulted in networks and knowledge that were valuable for crisis moments. Pure humanitarian actors also strategically reached out to authorities who were 'not essential' to their relief work, such as monastery leaders, to increase their acceptance (IO\#10, 30 January 2018).

Closed gatherings of humanitarian actors, such as the Rakhine cluster, where all operating INGOs and IOs met weekly in Sittwe, and the country-wide Humanitarian 
Country Team and INGO forum in Yangon, were presented as important for exchanging information, lobbying and advocating in a context where openly doing so alone is ineffective and possibly dangerous. The INGO representative (\#5, 11 January 2018) who mentioned cases of involuntary, military-assisted relocation of disaster-impacted Muslims in Rakhine was asked whether his organisation had spoken out on this issue; he responded, 'we deal with this with the Humanitarian Country Team. We are not so stupid as to do it alone'. However, group advocacy seemed to focus mostly on technical issues, such as a disaster law or relaxing customs for imported relief goods.

International strategy 4: Fishing for civil society actors with financial incentives As CSOs were reluctant to assist Muslim groups in Rakhine, one large INGO reported negotiating 'overhead costs' with LNGOs. This approach tied funding to the condition of providing help to the most marginalised groups, although, it seems, never explicitly to minorities. An INGO staff member (\#11, 10 January 2018) referred to extra 'incentive' payments for LNGOs that would otherwise not have worked as their flood-response implementing partners in sensitive areas such as northern Rakhine. Later in the interview, however, this staff member denied using that term.

These financial incentives did not always convince LNGOs. The director of a larger LNGO unaffiliated with any minority (\#15, 24 January 2018) explained that his organisation only applied for this conditional funding if the amount was large. Otherwise, 'there is a common understanding of our focus: hardest hit, women, [the] elderly [and] children. Marginalised and discriminated groups [are] not a part of it. We do not even know who that is'.

\section{Conclusion}

The findings for both States revealed minority marginalisation practices by the Myanmar Union government, with especially severe cases in Rakhine State. To support disaster victims of Chin ethnicity, parallel minority and diaspora networks were mobilised. Relief, which was not always distributed in a transparent or unbiased manner, was channelled from ethnically and religiously affiliated groups within and outside of Myanmar. Strong civil society structures and ties between Christian LNGOs and INGOs also increased support, or at least attention, from the international humanitarian system. Navigating an aid system that is itself adjusting to the recent political and humanitarian developments in Myanmar, proactive Chin individuals carefully selected their lobbying strategies, targets and allies. Some selectively foregrounded or backgrounded their ethnic identity depending on whether their interlocutor would be receptive to a more political minority discourse.

For the most marginalised disaster victims in Rakhine State, however, the Muslim and especially the Rohingya minority identity led to a dead end rather than to parallel civil society support channels. Civil society and diaspora actors were unwilling or unable to support Muslims, leaving the task to international humanitarians. Deeming it too risky to advocate openly, international humanitarian actors devoted significant effort to navigating the governmental barriers and the social and political tensions inherent in supporting highly stigmatised minorities. This included closely monitoring authorities' and different societal groups' perceptions of their organisations and activities and reaching out to Buddhist communities, religious institutions and governmental actors to increase acceptance. For many, '50/50' became the new targeting standard, openly departing from the principles of humanity and impartiality for the sake of minimising tensions. Ultimately, in a context where perceptions and even strategic decisions such as targeting are manipulated, the humanitarians largely ended up being played by the government system, which wanted humanitarians to be seen as targeting only Muslims.

This article has mostly examined the perceptions of Chin civil society and international humanitarian actors. It left out the private sector (which is increasingly involved in providing and/or channelling resources following disasters in Myanmar), insurgent militarised actors, regional actors such as the Association of Southeast Asian Nations, and policy makers at global humanitarian headquarters. Additional research considering these actors' realities would likely uncover a larger variety of state interactions and navigation strategies, involving informal aid delivery and hidden diplomacy practices.

Two major points can be drawn from the present findings. First, it is striking that a parallel system set up specifically to support marginalised groups-whether led by civil society, as was the case for the Chin, or by international actors, as was seen for Muslims in Rakhinecan be considered the only viable short-term solution. In the long-term, such parallel systems may increase feelings of exclusion and deepen the divide between antagonistic societal groups and between the Myanmar government and the international community.

Second, especially in the context of rising identity politics, humanitarian governance encompasses the governance of perceptions. Navigating the multiple and rapidly evolving LIC realities is difficult even within a single country, especially for aid organisations with country-wide mandates. As seen in the 2015 Komen response, satisfying the expectations of the multiple audiences is nearly impossible: Should one risk compromising government authorisations, community 
acceptance and associated security, or the principle of impartiality and, possibly, international funding? Balancing between governing various perceptions and allocating aid resources according to humanitarian principles involves largely unavoidable trade-offs that must be carefully evaluated by practitioners and policy makers.

Harvey (2013) states that, even in conflict settings where governments fail to fulfil their responsibilities, humanitarians should engage governments at the policy, technical and practical levels through the framework of humanitarian principles, despite the dilemmas this involves. Although I agree with this point, it is not only a humanitarian agenda that 'attempts to ring-fence an ever-shrinking isolationist humanitarian space' (Harvey 2013 , p. 167) that can be problematic. Disaster responders choosing to 'water down the humanitarian space' to safeguard good relations with the state or one community group risk becoming trapped in an increasingly restricted space, achieving little more than staying afloat. This can set precedents for state-humanitarian interaction and further tip the power balance in favour of the state. One telling example is that, by the time of the 2018 Rohingya crisis response in Myanmar, it had reportedly become 'standard' for a key IO to dispatch their relief 'without expats' and always accompanied by government officials (IO\#10, 30 January 2018). In authoritarian LIC settings, assessing in which cases confrontation might be needed remains a major challenge. Because high-level declarations are less adapted to these settings, negotiations at the operational level are key.

\section{Endnotes}

${ }^{1}$ In this article, I use the term 'Myanmar', mirroring the usage of most of the research participants. The use of the term does not reflect partiality in a context where the political opposition rejected the term 'Myanmar', which was unilaterally imposed by military rulers in 1989.

${ }^{2}$ Roughly $70 \%$ of the Myanmar population are of Bamar ethnicity (1983 Census, Desaine 2011, p. 28), and $78.9 \%$ are Buddhists (2014 Census, Myanmar Ministry of Information 2014). For decades, the government has aimed to 'homogenise the multifaceted ethnic and cultural mosaic [that is Myanmar] into a national, unified, Bamar entity' (Desaine 2011, p. 12). The government recognises 135 different ethnic groups, excluding the Rohingya, as belonging to the nation (Myanmar Ministry of Information 2018).

${ }^{3}$ MSF has come to be 'associated with the figure of the humanitarian as witness' who denounces human suffering (Décobert 2016, p. 21; Fassin 2007).

${ }^{4}$ For example, in the Sendai UN Disaster Risk Reduction Framework for Action (UN International Strategy for Disaster Reduction 2015) and the UN agenda on indigenous peoples and disasters (UN International Strategy for Disaster Reduction 2008).

${ }^{5}$ Statements drawn from interviews or focus group discussions are presented with information on the type of actor and date. Here, a statement is extracted from community member \#8 during a focus group discussion held on 22 November 2017.

${ }^{6}$ According to the Household Living Conditions Assessment survey conducted by the UN Development Programme (2011), approximately $73 \%$ of the Chin State population lives below the poverty line. Rakhine State has the second highest poverty rate in Myanmar, at $44 \%$.

${ }^{7}$ The policies enforced by subsequent regimes, from the British colonial 'divide-and-rule' to Myanmar government policies of exclusion and ethnicisation, have reinforced ethnic boundaries around the numerous and diverse population groups (Farzana 2010).

${ }^{8}$ To maintain confidentiality, the respondent identification number is not disclosed here.

${ }^{9}$ For example, no photos where aid workers' faces are recognisable and no pre-election expressions of political affiliations are allowed.

\section{Abbreviations}

CBO: Community-based organisation; CCERR: Chin Committee for Emergency Response and Rehabilitation; CSO: Civil society organisation; ECHO: European Civil Protection and Humanitarian Aid Operations; HIIK: Heidelberg Institute for International Conflict Research; INGO: International non-governmental organisation; IO: International organisation; LIC: Low-intensity conflict; LNGO: Local non-governmental organisation; MoU: Memorandum of understanding; MSF: Médecins Sans Frontières; UN: United Nations

\section{Acknowledgements \\ The author thanks the respondents and fieldwork facilitators, who must remain anonymous. Gratitude also goes to Dorothea Hilhorst, DisCoRD team members and Michaela Hordijk for their valuable comments during and after the fieldwork, and to Jennifer Barrett for language editing.}

\section{Funding}

This article was written as part of the $\mathrm{VICl}$ scheme (project no. 453/14/013), financed by the Netherlands Organisation for Scientific Research (NWO).

\section{Availability of data and materials \\ Transcripts of all interviews and field notes, as well as respondent details, are separately stored in a data vault belonging to the author. The data analysed for the current study are available from the corresponding author on reasonable request. However, to preserve confidentiality, respondent details (name, organisation and geographical area of intervention) will not be disclosed.}

\section{Authors' contributions}

The author read and approved the final manuscript.

\section{Competing interests}

The author declares that she has no competing interests.

\section{Publisher's Note}

Springer Nature remains neutral with regard to jurisdictional claims in published maps and institutional affiliations. 
Received: 24 October 2018 Accepted: 5 February 2019

Published online: 28 March 2019

\section{References}

Alles D (2012) Depoliticizing natural disasters to enhance human security in a sovereignty-based context: lessons from Aceh (2004) to Yangon (2008). In: Teh Cheng guan B (ed) human security. Springer Netherlands, Dordrecht, pp 157-172

Azar E (1990) The management of protracted social conflict: theory and and cases. Darmouth, Hampshire

Braun V, Clarke V (2006) Using thematic analysis in psychology. Qual Res Psychol 3:77-101. https://doi.org/10.1191/1478088706qp063oa

British Broadcasting Corporation (2012) Burma blocks opening of office for Islamic body OIC. [Online] Available from: https://www.bbc.com/news/worldasia-19949414. Accessed 16 Jan 2019

Burma Times Editor (2015) Aid absent for most Rohingyas. The Burma Times [Online] Available from: http://www.burmatimes.net/aid-absent-for-mostrohingyas/. Accessed 15 Jun 2016

CDA Collaborative Learning Projects (2009) Listening project: field visit report Myanmar/Burma. Collaborative for Development Action, Cambridge

Centre for Peace and Conflict Studies (2009) Listening to voices from inside: Myanmar's civil society response to cyclone Nargis. [online]. Available from: http://www.centrepeaceconflictstudies.org/publications/browse/listening-tovoices-from-inside-myanmar-civil-society-response-to-cyclone-nargis/. Accessed 11 Jan 2019

Cheesman N (2017) How in Myanmar 'National Races' came to surpass citizenship and exclude Rohingya. J Contemporary Asia 47:461-483. https:// doi.org/10.1080/00472336.2017.1297476

Chin Committee for Emergency Response and Rehabilitation (2015) The Chin State floods \& landslides: a community-led response and assessment. Chin Committee for Emergency Relief and Rehabilitation, Hakha

Chin Committee for Emergency Response and Rehabilitation (2018) CCERR's statement over Chin State government's management of aids for natural disaster. Chin Committee for Emergency Response and Rehabilitation, Hakha

Currie K (2012) Burma in the balance: the role of foreign assistance in supporting Burma's democratic transition. The project 2049 Institute, Arlington

Davey E, Borton J, Foley M (2013) A history of the humanitarian system Western origins and foundations. Overseas Development Institute Humanitarian Policy Group, London

Décobert A (2016) The politics of aid to Burma: a humanitarian struggle on the Thai-Burmese border. Routledge, Oxon

del Valle H, Healy S (2013) Humanitarian agencies and authoritarian states: a symbiotic relationship? Disasters 37:188-201. https://doi.org/10.1111/disa. 12021

Desaine $L$ (2011) The politics of silence: Myanmar NGOs' ethnic, religious and political agenda. Institut de Recherche sur l'Asie du Sud-Est Contemporaine (IRASEC), Bangkok

Desportes I, Mandefro H, Hilhorst D (2019) The humanitarian theatre: drought response during Ethiopia's low-intensity conflict of 2016. J Mod Afr Stud 57(1):1-29. https://doi.org/10.1017/S0022278X18000654

Douma NW, Hilhorst D (2006) Are we making a difference?' Cordaid policy and practice in addressing complex political emergencies: the case of Sudan. In: Working on peace-building and conflict prevention: experiences and dilemmas of Dutch NGOs. Dutch University Press, Amsterdam, pp 47-84

Drew E (2016) Myanmar case study: impact of conflict on CSOs. Oxfam Myanmar, Yangon

Duffield M (1997) NGO relief in war zones: towards an analysis of the new aid paradigm. Third World Q 18:527-542. https://doi.org/10.1080/ 01436599714858

Duffield M (2008) On the edge of 'No Man's Land': chronic emergency in Myanmar. University of Bristol, Bristol

Dufour C, de GV, Maury H, Grünewald F (2004) Rights, standards and quality in a complex humanitarian space: is sphere the right tool? Disasters 28:124-141. https://doi.org/10.1111/j.0361-3666.2004.00248.x

European Civil Protection and Humanitarian Aid Operations (2015) Myanmar/ Burma: still suffering from the impact of cyclone Komen. [online]. Available from: http://ec.europa.eu/echo/field-blogs/photos/myanmarburma-stillsuffering-impact-cyclone-komen en. Accessed 17 July 2018.

Farzana KF (2015) Boundaries in shaping the Rohingya identity and the shifting context of borderland politics. Stud Ethn Natl 15:292-314. https://doi.org/10. $1111 /$ sena.12142
Fassin D (2007) Humanitarianism as a politics of life. Publ Cult 19:499-520. https://doi.org/10.1215/08992363-2007-007

Flanigan ST (2008) Nonprofit service provision by insurgent organizations: the cases of Hizballah and the Tamil Tigers. Stud Conflict Terrorism 31:499-519. https://doi.org/10.1080/10576100802065103

Flanigan ST, Asal V, Brown M (2015) Community service provision by political associations representing minorities in the Middle East and North Africa. Voluntas 26:1786-1804. https://doi.org/10.1007/s11266-014-9516-4

Fortman G (2006) Poverty as a failure of entitlement: do rights-based approaches make sense? In: Williams L (ed) International poverty law: an emerging discourse. Zed Books, London, pp 34-48

Galtung J (1996) Part Il: conflict theory. In: Peace by peaceful means: peace and conflict, development and civilization. Sage Publications, Thousand Oaks, pp 70-80

Glasius M (2018) What authoritarianism is ... and is not: a practice perspective. Int Aff 94:515-533. https://doi.org/10.1093/ia/iiy060

Glasius M, de Lange M, Bartman J, Dalmasso E, Lv A, Del Sordi A, Michaelsen M, Ruijgrok K (2018) Research, ethics and risk in the authoritarian field. Springer International Publishing, Cham

Harvey P (2013) International humanitarian actors and governments in areas of conflict: challenges, obligations, and opportunities. Disasters 37:151-170. https://doi.org/10.1111/disa.12019

Heidel B (2006) The growth of civil society in Myanmar. Books for Change, Bangalore

Heidelberg Institute for International Conflict Research (HIIK) (2016) Conflict barometer 2015. The Heidelberg Institute for International Conflict Research, Heidelberg

Hilhorst D (ed) (2013) Disaster, conflict and society in crises: everyday politics of crisis response. Routledge, Oxon

Hilhorst D (2016) Aid-society relations in humanitarian crises and recovery. Institute of Social Studies of Erasmus University Rotterdam, The Hague

Hilhorst D, Baart J, van der Haar G, Leeftink FM (2015) Is disaster 'normal' for indigenous people? Indigenous knowledge and coping practices. Disaster Prev Manag 24:506-522. https://doi.org/10.1108/DPM-02-2015-0027

Human Security Report Project (2013) The decline in global violence: evidence, explanation, and contestation. [online]. Available from: https://www.files.ethz. ch/isn/178122/HSRP_Report_2013_140226_Web.pdf. Accessed 25 Jul 2016

Hutchison E (2014) A global politics of pity? Disaster imagery and the emotional construction of solidarity after the 2004 Asian tsunami. Int Political Sociol 8: 1-19. https://doi.org/10.1111/ips.12037.

International Crisis Group (2006) Myanmar: new threats to humanitarian aid. International Crisis Group, Bangkok/Brussels

Jackson M (1998) Minima Ethnographica: intersubjectivity and the anthropological subject. University of Chicago Press, Chicago

Jacoby T, Özerdem A (2008) The role of the state in the Turkish earthquake of 1999. J Int Dev 20:297-310. https://doi.org/10.1002/jid.1415

Kahn C, Cunningham A (2013) Introduction to the issue of state sovereignty and humanitarian action. Disasters 37:139-150. https://doi.org/10.1111/disa.12018

Kalyvas SN (2003) The ontology of "political violence": action and identity in civil wars. Perspect Polit 1:475-494. https://doi.org/10.1017/S1537592703000355

Kang L (2012) Transnational humanitarian aid in Burma. Peace Rev 24:349-358. https://doi.org/10.1080/10402659.2012.704326

King E, Mutter J (2014) Violent conflicts and natural disasters: the case for crossdisciplinary dialogue. Third World Q 35:1239-1255. https://doi.org/10.1080/ 01436597.2014 .926113

Kipgen N (2013) Conflict in Rakhine State in Myanmar: Rohingya Muslims' conundrum. J Muslim Minority Aff 33:298-310. https://doi.org/10.1080/ 13602004.2013.810117

Koenig M, de Guchteneire PFA (eds) (2007) Democracy and human rights in multicultural societies. UNESCO Publishing, Paris

Lee $R$ (2016) The dark side of liberalization: how Myanmar's political and media freedoms are being used to limit Muslim rights. Islam Christian-Muslim Relat 27:195-211. https://doi.org/10.1080/09596410.2016.1159045

Lyons T (ed) (2014) Humanitarian aid and conflict : from humanitarian neutralism to humanitarian intervention. In: Routledge handbook of African security. Routledge, Oxon, pp 137-146

Mark S (2016) "Fragmented sovereignty" over property institutions: developmental impacts on the Chin Hill communities. Indep J Burmese Scholarship 1(1):125-160

Matelski M (2016a) Civil society, foreign aid, and donor dependency in transitional Myanmar. In: Kosem S (ed) Border twists and Burma trajectories. Perceptions, reforms, and adaptations. Center for ASEAN Studies, Chiang Mai University, Chiang Mai, pp 93-126 
Matelski M (2016b) Constructing civil society in Myanmar: struggles for local change and global recognition. Unpublished PhD thesis. Vrije Universiteit Amsterdam, Amsterdam

Myanmar Ministry of Information (2014) Religious data of 2014 Census released. [Online]. Available from: http://www.moi.gov.mm/moi:eng/?q=news/14/11/ 2018/id-7783. Accessed 11 Jan 2019

Myanmar Ministry of Information (2018) Pyithu Hluttaw discusses classification of ethnic nationals. [Online]. Available from: http://www.moi.gov.mm/moi:eng/ ?q=news/14/11/2018/id-12679. Accessed 11 Jan 2019

National Natural Disaster Management Committee (2015a) Situation Report No.3 - National Natural Disaster Management Committee, 24 August 2015. National Natural Disaster Management Committee, Nay Pyi Daw

National Natural Disaster Management Committee (2015b) Situation Report No.4 - National Natural Disaster Management Committee, 2 September 2015. National Natural Disaster Management Committee, Nay Pyi Daw

Paik W (2011) Authoritarianism and humanitarian aid: regime stability and external relief in China and Myanmar. Pac Rev 24:439-462. https://doi.org/10. 1080/09512748.2011.596560

Parnini SN (2013) The crisis of the Rohingya as a Muslim minority in Myanmar and bilateral relations with Bangladesh. J Muslim Minority Aff 33:281-297. https://doi.org/10.1080/13602004.2013.826453

Pelling M, Dill K (2010) Disaster politics: tipping points for change in the adaptation of sociopolitical regimes. Prog Hum Geogr 34:21-37. https://doi. org/10.1177/0309132509105004

Peters K (2017) The next frontier for disaster risk reduction. Overseas Development Institute, London

Renshaw CS (2013) Democratic transformation and regional institutions: the case of Myanmar and ASEAN. J Curr Southeast Asian Aff 32:29-54

Sakhong LH (2007) Christianity and Chin identity. In: Gravers M (ed) Exploring ethnic diversity in Burma. Nordic Institute of Asian Studies, Copenhaguen, pp 200-226

Schennink BG, van der H, Hilhorst D, van der Borgh (2006) Working on peace building and conflict prevention: reflection on the findings. In: Schennink $G$, van der Haar (eds) Working on peace-building and conflict prevention: experiences and dilemmas of Dutch NGOs. Dutch University Press, Amsterdam, pp 203-217

Selth A (2008) Even paranoids have enemies: cyclone Nargis and Myanmar's fears of invasion. Contemporary Southeast Asia 30:379-402. https://doi.org/10. $1355 / \operatorname{cs} 30-3 b$

Selth A (2018) Myanmar Watching: Problems and Perspectives. Griffith University, Brisbane

Sifton J (2014) Dispatches: a scathing verdict on Burma's stalled reforms - Human Rights Watch. [Online]. Available from: https://www.hrw.org/news/2014/10/ 17/dispatches-scathing-verdict-burmas-stalled-reforms. Accessed 14 Jun 2016

Smith M (2010) Ethnic politics in Myanmar: a year of tension and anticipation. Southeast Asian Aff 36(1):214-234

South A, Kempel S, Perhult M, Carstensen N, Sudan SS (2011) Myanmar-surviving the storm: self-protection and survival in the delta. Local to Global Protection, Copenhagen

Summer A, Tribe M (2008) International development studies: theories and methods in research and practice. SAGE, London

Taylor RH (1982) Perceptions of ethnicity in the politics of Burma. Southeast Asian J Soc Sci 10:7-22

Trihartono A (2018) Myanmar's worsening Rohingya crisis: a call for responsibility to protect and ASEAN's response. In: McLellan B (ed) Sustainable future for human security: society. Cities and Governance. Springer Singapore, Singapore, pp 3-16

UN Development Program (2011) Integrated Household Living Conditions Survey in Myanmar 2009-2010-MDG Data. United Nations Development Program, Yangon

UN International Strategy for Disaster Reduction (2008) Indigenous knowledge for disaster risk reduction: good practices and lessons learned from experiences in the Asia-Pacific region. United Nations, New York

UN International Strategy for Disaster Reduction (2015) Sendai framework for disaster risk reduction 2015-2030. [Online]. Available from: http://www. preventionweb.net/files/43291_sendaiframeworkfordrren.pdf. Accessed 23 Nov 2016.

UN Office for the Coordination of Humanitarian Affairs (2015a) Myanmar floods and landslides 2015. [Online]. Available from: https://reliefweb.int/disaster/fl2015-000080-mmr. Accessed 6 Oct 2018
UN Office for the Coordination of Humanitarian Affairs (2015b) Myanmar: flood affected areas (3 Aug 2015). [Online]. Available from: https://reliefweb.int/map/ myanmar/myanmar-flood-affected-areas-3-aug-2015. Accessed 22 Aug 2018.

United Nations (2018) OHCHR human rights council complaint procedure report of the independent international fact-finding mission on Myanmar. [Online]. Available from: https://www.ohchr.org/EN/HRBodies/HRC/ MyanmarFFM/Pages/Index.aspx. Accessed 24 Sept 2018.

Vigh H (2009) Motion squared: a second look at the concept of social navigation. Anthropological Theory 9:419-438. https://doi.org/10.1177/ 1463499609356044

van Voorst R, Hilhorst D (2017) Humanitarian action in disaster and conflict settings - insights of an expert panel. International Institute of Social Studies, The Hague

Wade F (2017) Myanmar's enemy within : Buddhist violence and the making of a Muslim "other". Zed Books, London

Wallis K, Jacquet C (2011) Local NGOs in Myanmar: vibrant but vulnerable. Overseas Development Institute Humanitarian Practice Network, London [Online]. Available from: https://odihpn.org/magazine/local-ngos-inmyanmar-vibrant-but-vulnerable/. Accessed 22 Aug 2018

Zaw TN, Lim S (2017) The military's role in disaster management and response during the 2015 Myanmar floods: a social network approach. Int JDisaster Risk Reduct 25:1-21. https://doi.org/10.1016/j.jjdrr.2017.06.023

Zyck S, Krebs H (2015) Localising humanitarianism: improving effectiveness through inclusive action. Overseas Development Institute Humanitarian Policy Group, London

\section{Submit your manuscript to a SpringerOpen ${ }^{\odot}$ journal and benefit from:}

- Convenient online submission

- Rigorous peer review

- Open access: articles freely available online

- High visibility within the field

- Retaining the copyright to your article

Submit your next manuscript at $>$ springeropen.com 